\title{
FORMULASI AUKSIN (INDOLE ACETIC ACID) DAN SITOKININ (KINETIN, ZEATIN) UNTUK MORFOGENESIS SERTA PENGARUHNYA TERHADAP PERTUMBUHAN, SINTASAN DAN LAJU REGENERASI KALUS RUMPUT LAUT, Kappaphycus alvarezii
}

\author{
Sri Redjeki Hesti Mulyaningrum*), Andi Parenrengi", Yenny Risjani**, \\ dan Happy Nursyam**) \\ *) Balai Penelitian dan Pengembangan Budidaya Air Payau \\ Jl. Makmur Dg. Sitakka No. 129, Maros 90512, Sulawesi Selatan \\ E-mail: titut_suryanto@yahoo.com \\ **t) Fakultas Perikanan dan IImu Kelautan, Universitas Brawijaya, Malang \\ Jl. Veteran, Malang 65145
}

(Naskah diterima: 13 Desember 2012; Disetujui publikasi: 28 Februari 2013)

\begin{abstract}
ABSTRAK
Interaksi auksin dan sitokinin dianggap penting untuk mengatur pertumbuhan dan perkembangan dalam kultur jaringan tanaman. Penelitian ini bertujuan untuk menentukan komposisi auksin dan sitokinin yang optimum untuk morfogenesis kalus rumput laut $K$. alvarezii, dan mengevaluasi pengaruhnya terhadap pertumbuhan, sintasan, dan laju regenerasi kalus. Kultur kalus dilakukan pada media cair dengan formulasi zat pengatur tumbuh (ZPT) indole acetic acid (IAA) : kinetin : zeatin, dengan komposisi konsentrasi sebagai berikut: A) 0,4:0:1 mg/L; B) 0,4:0,25:0,75 mg/L;C) 0,4:0,5:0,5 mg/L; D) 0,4:0,75:0,25 mg/L; E) 0,4: $1: 0 \mathrm{mg} / \mathrm{L}$; kontrol (tanpa ZPT). Desain penelitian adalah rancangan acak lengkap dengan pengulangan tiga kali untuk masingmasing perlakuan. Parameter yang diamati adalah laju pertumbuhan harian, sintasan, laju regenerasi, panjang tunas, dan morfologi tunas. Analisis data dilakukan dengan uji keragaman (ANOVA) dan hasil yang diperoleh disajikan dalam bentuk grafik. Hasil penelitian menunjukkan bahwa formula optimum untuk morfogenesis rumput laut $K$. alvarezii adalah formula A dengan komposisi IAA : zeatin $=0,4: 1 \mathrm{mg} / \mathrm{L}$. Penggunaan formula zat pengatur tumbuh yang berbeda berpengaruh nyata $(P<0,05)$ terhadap laju pertumbuhan harian, laju regenerasi dan panjang tunas yang dihasilkan, tetapi tidak berpengaruh nyata $(P>0,05)$ terhadap sintasan kalus. Tunas rumput laut $K$. alvarezii mulai terbentuk pada hari ke-15 masa kultur.
\end{abstract}

KATA KUNCl: formulasi, auksin, sitokinin, morfogenesis, K. alvarezii

ABSTRACT: Formulation of auxin (Indole Acetic Acid) and cytokinin (Kinetin, Zeatin) for morphogenesis and its effect to the growth rate, survival rate, and regeneration rate of Kappaphycus alvarezii callus. By: Sri Redjeki Hesti Mulyaningrum, Andi Parenrengi, Yenny Risjani, and Happy Nursyam

Interaction of auxin-cytokinin is important for regulation of growth and development in tissue culture. This research aims to determine optimum formula of auxin and cytokinin for morphogenesis and evaluate the effect of formula to the growth rate, survival rate, and regeneration rate of $\mathrm{K}$. alvarezii callus. Callus was cultured on liquid media with plant growth regulator (PGR) formulation of indole acetic acid (IAA) : kinetin : zeatin, the formulations were: A) 0.4:0:1 $\mathrm{mg} / \mathrm{L}$; B) 0.4:0.25:0.75 $\mathrm{mg} / \mathrm{L}$; C) 
0.4:0.5:0.5 mg/L; D) 0.4:0.75:0.25 mg/L; E) 0.4:1:0 mg/L; control (without PGR). Research was designed with completely randomized design with 3 replications of each treatment. Observed parameters were daily growth rate, survival rate, regeneration rate, length of shoots, and morphology of shoots. Data was analyzed with one way ANOVA. The results showed that the optimum formula for morphogenesis of $K$. alvarezii was formula $A$, the composition was IAA : zeatin in $0.4: 1 \mathrm{mg} / \mathrm{L} \mathrm{ratio.}$ Different plant growth regulator formula had significantly different in daily growth rate, regeneration rate, and average length of shoots $(P<0.05)$, but there was no significantly different in survival rate $(P>0.05)$. The shoots of $K$. alvarezii began to regenerate in 15 days culture.

\section{KEYWORDS: formulation. auxin, cytokinin, morphogenesis, K. alvarezii}

\section{PENDAHULUAN}

Rumput laut K. alvarezii merupakan salah satu jenis rumput laut yang banyak dibudidayakan, dan menjadi salah satu komoditas perikanan yang penting. Kebutuhan pasar rumput laut $K$. alvarezii semakin meningkat, sehingga kebutuhan bibit dalam jumlah yang besar mutlak diperlukan. Salah satu upaya untuk menyediakan bibit secara kontinu adalah melalui kultur jaringan. Perkembangan mikropropagasi tanaman melalui kultur jaringan memberikan prospek yang menjanjikan bagi pengembangan bioteknologi tanaman, peluang yang besar pada manipulasi genetik, propagasi tanaman, dan produksi tanaman komersial. Kesuksesan teknik-teknik mikropropagasi pada tumbuhan tingkat tinggi mendorong pengembangannya pada rumput laut yang secara umum bertujuan untuk meningkatkan ekonomi melalui peningkatan produksi rumput laut. Salah satu metode kultur jaringan rumput laut yang sering digunakan adalah induksi kalus. Teknik ini banyak digunakan untuk propagasi klon dan perbaikan mutu genetik untuk mendukung ketersediaan benih yang kontinu dan berkualitas (Reddy et al., 2008a; Parenrengi et al., 2007).

Penggunaan media kultur yang sesuai merupakan syarat yang harus terpenuhi pada kultur jaringan. Salah satu komponen media kultur yang sangat diperlukan untuk proses morfogenesis adalah zat pengatur tumbuh (ZPT). Pertumbuhan kalus dan organ-organ ditentukan oleh penggunaan zat pengatur tumbuh secara tepat. Tanpa penambahan zat pengatur tumbuh dalam media, pertumbuhan sangat terhambat bahkan mungkin tidak tumbuh sama sekali (Prakoeswa et al., 2009).

Zat pengatur tumbuh jenis auksin dan sitokinin dianggap penting untuk mengatur pertumbuhan dan perkembangan dalam kultur jaringan tanaman. Penelitian mengenai penggunaan zat pengatur tumbuh auksin dan sitokinin dalam kultur jaringan rumput laut telah banyak dilakukan pada beberapa spesies rumput laut, di antaranya K. alvarezii (Reddy et al., 2003; Hayashi et al., 2008); Gelidiella acerosa (Kumar et al., 2004); Halimenia sinensis (Wang et al., 2006); serta K. striatum (Hurtado et al., 2009). Dari hasil penelitian terdahulu diperoleh informasi bahwa setiap spesies rumput laut memiliki respons yang berbeda terhadap zat pengatur tumbuh.

Pembelahan sel diatur oleh aksi bersama auksin dan sitokinin. Masing-masing mempengaruhi fase berbeda dari siklus sel. Komposisi auksin dan sitokinin dalam kultur perlu diatur secara seimbang dan dikendalikan secara hati-hati agar fase-fase dalam siklus sel seimbang sehingga morfogenesis dapat terlaksana dengan baik (Dewi, 2008). Dalam kultur jaringan rumput laut $K$. alvarezii penggunaan formula auksin dan sitokinin yang tepat sangat penting dilakukan agar proses morfogenesis dapat berjalan secara optimal. Penelitian ini bertujuan untuk menentukan komposisi auksin dan sitokinin yang optimum pada morfogenesis kalus rumput laut $K$. alvarezii, serta pengaruhnya terhadap pertumbuhan, sintasan, dan laju regenerasi kalus.

\section{BAHAN DAN METODE}

Penelitian dilaksanakan di Balai Penelitian dan Pengembangan Budidaya Air Payau Maros. Pada tahap awal penelitian dilakukan inisiasi dan proliferasi untuk memperoleh kalus rumput laut K. alvarezii. Pada tahap ini dilakukan induksi kalus dengan mengacu metode Reddy et al. (2003) yang dimodifikasi. Sampel rumput laut dipotong dengan ukuran $2 \mathrm{~cm}$, kemudian dicuci dengan air laut steril. Selanjutnya dilakukan sterilisasi eksplan dengan larutan 
iodin $0,1 \%$ selama tiga menit untuk menghilangkan mikroba. Sterilisasi dilanjutkan dengan antibiotik mix spektrum luas $0,1 \%$ dan dicuci dengan air laut steril sampai tiga kali. Selanjutnya dilakukan perendaman eksplan pada larutan 0,1\% antibiotik mix spektrum luas dalam media Conwy selama dua hari.

Eksplan kemudian dikeringkan dengan tissu steril untuk mengurangi kelembaban, kemudian dipotong-potong sepanjang 4-5 mm. Selanjutnya eksplan diinokulasi pada media agar $0,8 \%$ yang diperkaya dengan pupuk Conwy dengan kepadatan 20 eksplan/petridish. Kultur dilakukan pada suhu $20^{\circ} \mathrm{C}$ dengan penerangan lampu neon 1.500 lux fotoperiode terang: gelap $=12: 12$ selama 60 hari. Penggantian media dilakukan setiap tujuh hari dengan media baru yang sama dengan media sebelumnya. Perkembangan kalus diamati di bawah mikroskop (Bausch \& Lomb). Gambaran kalus yang terbentuk dipotret dengan kamera digital (Optika Microscopes CCD Sensor).

Tahap selanjutnya adalah kultur kalus pada media cair Conwy dengan ZPT auksin (IAA) dan sitokinin (kinetin dan zeatin) dengan perlakuan formulasi sebagai berikut: IAA : $\mathrm{ki}$ netin : zeatin = A) 0,4:0:1 mg/L; B) 0,4:0,25: $0,75 \mathrm{mg} / \mathrm{L}$; C) 0,4:0,5:0,5 mg/L; D) 0,4:0,75:0,25 $\mathrm{mg} / \mathrm{L}$; E) 0,4:1:0 mg/L; kontrol (tanpa ZPT). Masing-masing perlakuan diberi tiga ulangan. Kultur dilakukan selama 30 hari pada shaker dengan penerangan lampu neon berkekuatan 1.500 lux, fotoperiode terang : gelap $=12: 12$ pada suhu $20^{\circ} \mathrm{C}$. Setiap 15 hari dilakukan penggantian media dan pengamatan perkembangan morfologi. Pada akhir kultur dilakukan pengukuran laju pertumbuhan harian, sintasan, kecepatan regenerasi dalam setiap wadah, dan panjang tunas. Laju pertumbuhan harian dihitung dengan menimbang kalus dan dihitung menggunakan rumus berikut:

$$
\mathrm{LPH}=\frac{\ln \mathrm{Wt}_{\mathrm{t}} / \mathrm{Wo}_{\mathrm{O}}}{\mathrm{t}} \times 100 \%
$$

di mana:

$\mathrm{LPH}=$ Laju pertumbuhan harian (\%/hari)

$\mathrm{W}_{\mathrm{t}}=$ Bobot akhir kalus

$\mathrm{W}_{0}=$ Bobot awal kalus

$\mathrm{t}=$ Lama kultur

Sintasan diperoleh dengan menghitung kalus yang hidup. Adapun rumus sintasan adalah sebagai berikut:

$$
\mathrm{SR}=(\mathrm{Nt} / \mathrm{No}) \times 100 \%
$$

di mana:

$\mathrm{SR}=$ Sintasan (Survival rate) (\%)

$\mathrm{Nt}=$ Jumlah kalus yang hidup

No = Jumlah kalus awal

Kecepatan kalus beregenerasi dalam setiap wadah diukur dengan metode Yokoya et al. (2004) dengan menghitung jumlah kalus yang beregenerasi dalam setiap wadah. Perhitungan laju regenerasi dalam setiap wadah adalah sebagai berikut:

$$
\mathrm{R}=(\mathrm{Nr} / \mathrm{No}) \times 100 \%
$$

di mana:

$\mathrm{R}=$ Laju regenerasi (\%)

$\mathrm{Nr}=$ Jumlah kalus yang beregenerasi

No = Jumlah kalus awal

Panjang tunas diukur di bawah mikroskop (Olympus 1X71). Semua data yang diperoleh dianalisis dengan analisis ragam ANOVA, sedangkan data perkembangan morfologi disajikan secara deskriptif dari hasil pengamatan di bawah mikroskop.

\section{HASIL DAN BAHASAN}

\section{Inisiasi dan Proliferasi}

Pengamatan morfologi di bawah mikroskop menunjukkan adanya proses induksi kalus yang dimulai dengan pigmentasi pada permukaan eksplan (kortikal), kemudian terbentuk kalus pada bagian tengah (medular) dan lapisan kortikal. Kalus berwarna coklat tua, dan terdiri atas filamen yang berasal dari pembelahan sel yang dihasilkan sebagai respons dari luka di permukaan irisan. Hal ini sesuai dengan pendapat Rorrer \& Cheney (2004) yang menyatakan bahwa pembentukkan kalus dimulai dengan pigmentasi pada daerah permukaan eksplan, kemudian terbentuk kalus yang tidak terdiferensiasi dan berkembang menjadi tunas.

Kalus mulai terbentuk pada minggu ke-2 kultur, kemudian terbentuk filamen-filamen pada umur pemeliharaan 21 hari. Hasil ini sesuai dengan penelitian Munõz et al. (2006) dan Hayashi et al. (2008) yang melaporkan bahwa kalus $K$. alvarezii terbentuk setelah 16 dan 15 hari masa kultur. Waktu induksi ini lebih singkat dari waktu induksi rumput laut jenis Halymenia sinensis yang memerlukan waktu 50 hari untuk membentuk kalus (Wang et al., 
2006). Filamen berkembang pada sel medular rumput laut. Pada bagian tengah sel medular terjadi pigmentasi yang merupakan bagian dari filamen kalus. Filamen pada setiap kalus yang terbentuk terdiri atas dua jenis, yakni jenis kristal dan filamen berpigmen seperti terlihat pada Gambar 1.

Berbeda dengan rumput laut Turbinaria yang memiliki filamen kalus berserabut yang terbentuk pada pusat potongan eksplan dan filamen kalus yang berbentuk gelembunggelembung, K. alvarezii memiliki dua macam filamen kalus yaitu filamen berbentuk kristal dan filamen berpigmen. Sel filamen yang dihasilkan dalam penelitian ini berbentuk bulat (Gambar 2). Pada dasarnya bentuk sel filamen kalus rumput laut ada dua macam, yaitu filamen kalus liform dengan bentuk memanjang dan filamen kalus moniliform yang berbentuk bulat (Munõz et al., 2006; Kumar et al., 2007).

Pada proses inisiasi dan proliferasi, penambahan zat pengatur tumbuh IAA dapat menstimulasi pembentukkan kalus. Hal ini dapat dijelaskan karena zat pengatur tumbuh golongan auksin berperan dalam inisiasi pembelahan sel, dan organisasi dari meristem menjadi suatu jaringan tidak terorganisir (Yokoya et al., 2004; Gaspar et al., 1996). Kalus yang bersifat embriogenik berwarna coklat tua karena mengalami pigmentasi (Gambar 3a), sedangkan kalus yang tidak embriogenik berwarna pucat (Gambar 3b).
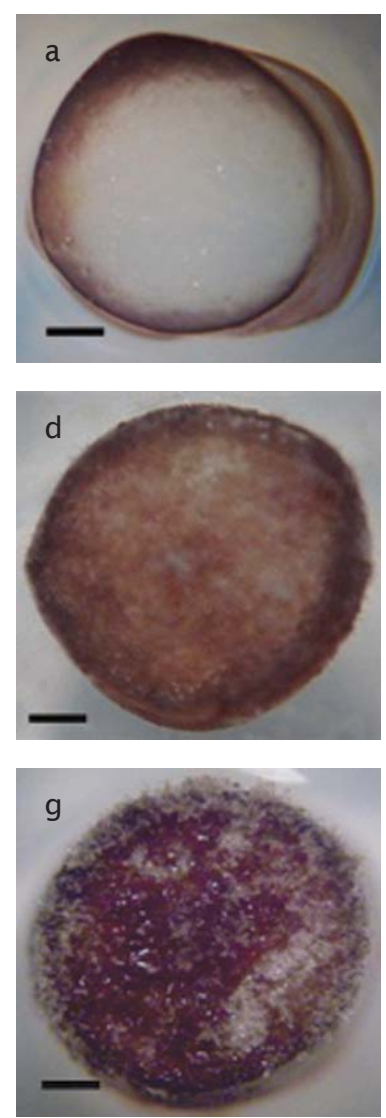
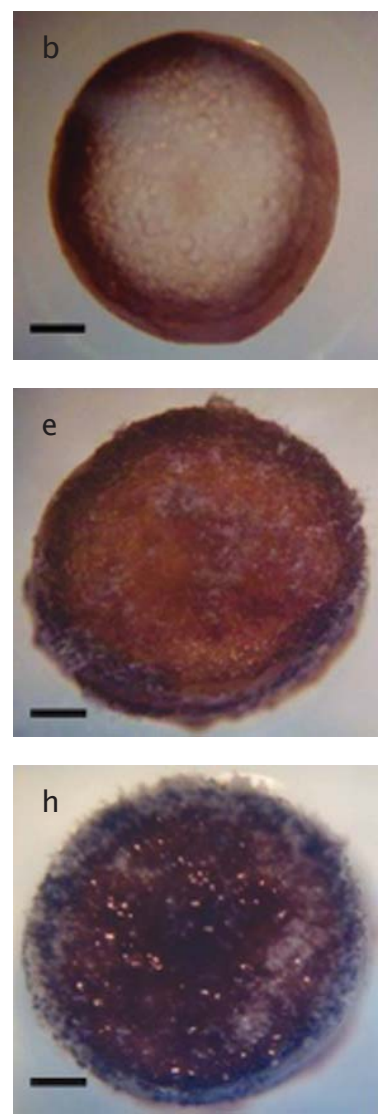
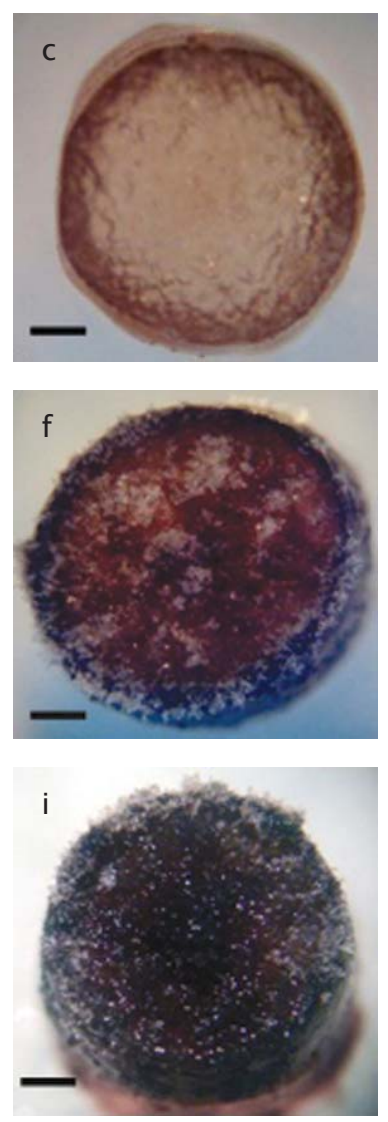

Gambar 1. Perkembangan kalus selama 60 hari pemeliharaan: a. awal kultur; b. minggu ke-1; c. minggu ke-2; d. minggu ke-3; e. minggu ke-4; f. minggu ke-5; g. minggu ke-6; h. minggu ke-7; i. minggu ke-8 (skala bar $=10 \mu \mathrm{m})$

Figure 1. Callus development in 60 days of culture: $a$. in the beginning of culture; $b$. first week; c. second week; $d$. third week; e. fourth week; f. fifth week; g. sixth week; h. seventh week; i. eighth week (scale bar $=10 \mu \mathrm{m})$ 


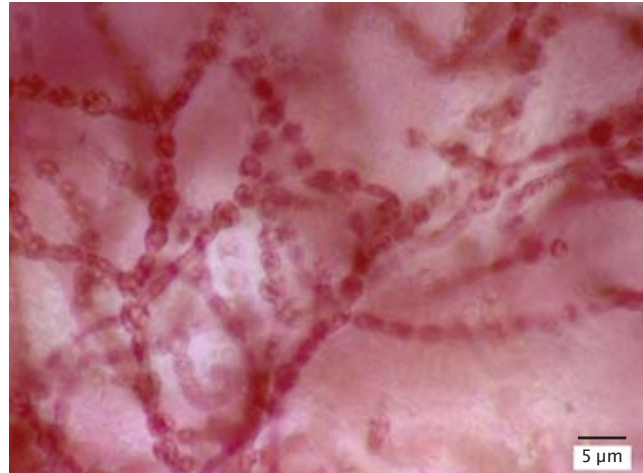

Gambar 2. Sel filamen kalus moniliform $K$. alvarezii (skala bar $=5 \mu \mathrm{m}$ )

Figure 2. Moniliform cell of filamentous callus of $K$. alvarezii (scale bar $=5 \mu \mathrm{m}$ )

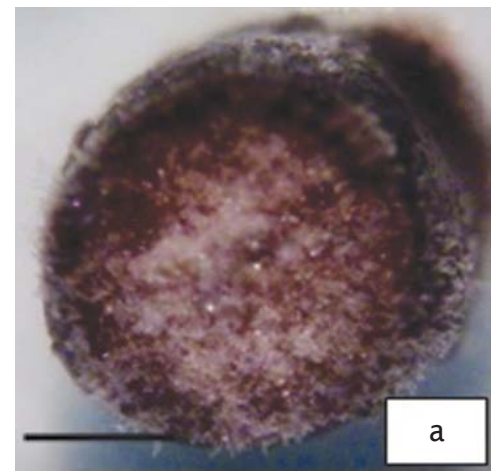

Gambar 3. Perbandingan kalus rumput laut K. alvarezii : (a) embriogenik; (b) tidak embriogenik (skala bar $=20 \mu \mathrm{m}$ )

Figure 3. Comparison of K. alvarezii callus: (a) embryogenic callus; (b) unembryogenic callus (scale bar $=20 \mu \mathrm{m}$ )

\section{Formulasi Auksin dan Sitokinin}

\section{Laju Pertumbuhan Harian}

Kisaran laju pertumbuhan harian yang dihasilkan pada penelitian ini adalah $0,44 \%$ $1,93 \% /$ hari. Nilai tertinggi diperoleh pada formula $\mathrm{A}(1,93 \% /$ hari) kemudian berturut-turut formula $E(1,56 \% /$ hari); formula $D(0,91 \% /$ hari); formula B $(0,72 \% /$ hari); formula C $(0,67 \% /$ hari); dan kontrol (0,44\%/hari). Hasil uji ragam (ANOVA) menunjukkan bahwa formula zat pengatur tumbuh yang berbeda memberikan pengaruh nyata $(P<0,05)$ terhadap laju pertumbuhan harian rumput laut. Laju pertumbuhan harian formula $A$ berbeda nyata dengan formula $B, C, D$, dan kontrol $(P<0,05)$, tetapi for-

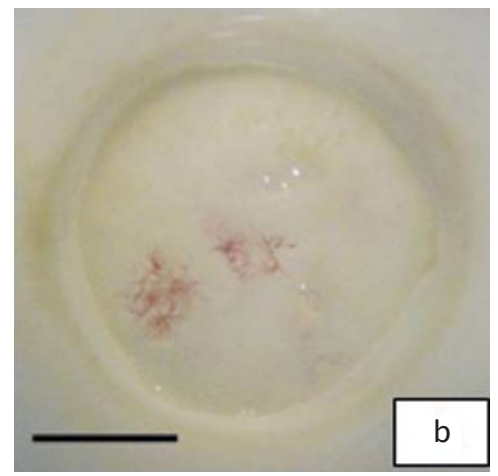

mula $A$ berbeda tidak nyata dengan formula $E$ $(P>0,05)$ (Gambar 4).

Laju pertumbuhan harian yang diperoleh pada penelitian ini lebih rendah dari hasil penelitian Huang et al. (1998) yang memperoleh laju pertumbuhan harian mikroplantlet Agardhiella subulata pada kisaran 2\%-3\%/hari. Formula dengan komposisi kinetin $(1 \mathrm{mg} / \mathrm{L}$ ) dan zeatin (1 mg/L) yang diberikan secara terpisah (formula $\mathrm{A}$ dan $\mathrm{E}$ ) memiliki laju pertumbuhan harian yang tinggi dibandingkan formula lain. $\mathrm{Hal}$ ini diduga karena penambahan kinetin (1 $\mathrm{mg} / \mathrm{L})$ dan zeatin $(1 \mathrm{mg} / \mathrm{L})$ secara terpisah mampu meningkatkan level salah satu hormon sitokinin endogen, sedangkan formula zat pengatur tumbuh yang memiliki komposisi dua jenis sitokinin sekaligus (formula B, C, dan D) tidak mampu meningkatkan level hormon 

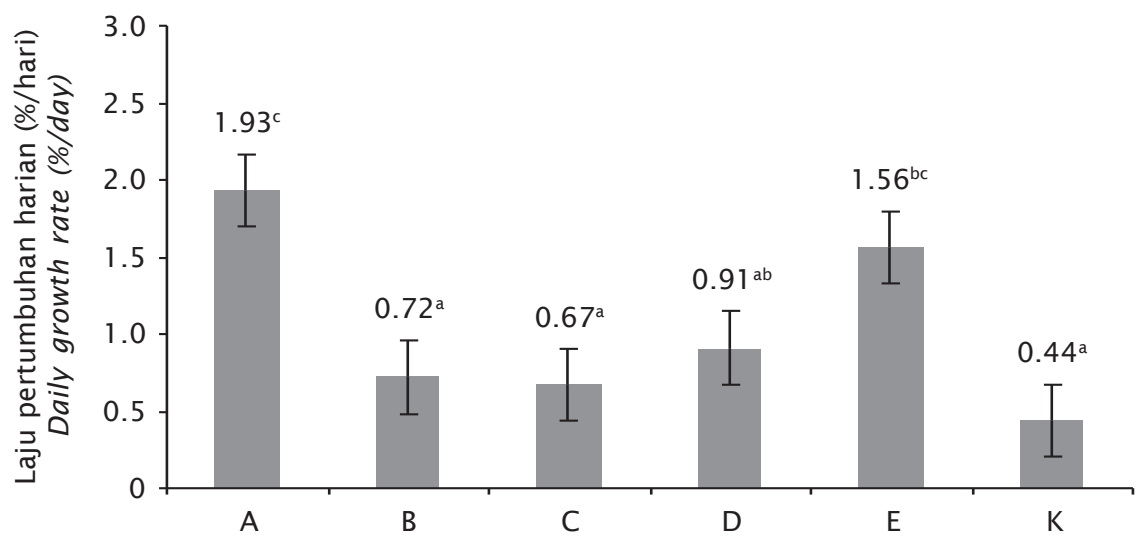

Formulasi auksin dan sitokinin Formulations of auxin and cytokinin

Keterangan (Note):

- IAA + kinetin + zeatin : $A=0,4: 0,1 \mathrm{mg} / \mathrm{L} ; B=0,4: 0,25: 0,75 \mathrm{mg} / \mathrm{L} ; C=0,4: 0,5: 0,5 \mathrm{mg} / \mathrm{L}$; $\mathrm{D}=0,4: 0,75: 0,25 \mathrm{mg} / \mathrm{L} ; \mathrm{E}=0,4: 1: 0 \mathrm{mg} / \mathrm{L} ; \mathrm{K}=$ Kontrol $(I A A+$ kinetin + zeatin : $A=0.4: 0.1$ $\mathrm{mg} / \mathrm{L} ; B=0.4: 0.25: 0.75 \mathrm{mg} / \mathrm{L} ; C=0.4: 0.5: 0.5 \mathrm{mg} / \mathrm{L} ; D=0.4: 0.75: 0.25 \mathrm{mg} / \mathrm{L} ; E=0.4: 1.0$ $\mathrm{mg} / \mathrm{L} ; \mathrm{K}=$ Control)

- Nilai yang diikuti oleh huruf yang sama setelah nilai rata-rata menunjukkan berbeda tidak nyata $(P>0,05)$ pada uji Duncan. Data disajikan dalam rata-rata \pm standar deviasi, $(\mathrm{n}=3$, setiap ulangan terdiri atas 4 kalus) (Values with the same superscripts after means value are not significantly different $(P>0.05)$ in Duncan test. Data are means \pm standard deviations ( $n=3$, each replicate with four calluses))

Gambar 4. Laju pertumbuhan harian kalus pada berbagai formulasi auksin dan sitokinin

Figure 4. Daily growth rate of callus in several auxin-cytokinin formulations

memperlihatkan bahwa penambahan zat pengatur tumbuh yang berbeda tidak berpengaruh nyata $(P>0,05)$ terhadap sintasan kalus. Hasil penelitian ini tidak jauh berbeda dengan hasil penelitian sebelumnya. Gonzalez et al. (2007) mendapati sintasan rata-rata sebesar $84,6 \%$ pada induksi kalus rumput laut jenis Gigartina skottsbergii sedangkan Munõz et al. (2006), mendapati sintasan kalus $K$. alvarezii pada kisaran 25\%-91\% dengan ukuran eksplan kurang dari $2 \mathrm{~cm}$.

Dari hasil pengamatan di laboratorium menunjukkan bahwa kematian kalus mulai terjadi pada minggu pertama kultur. Hal ini dapat terjadi karena pada awal kultur kalus masih beradaptasi dengan lingkungan kultur. Menurut Huang et al. (1998), kematian dapat diakibatkan karena kondisi filamen stres akibat pemindahan dari media padat ke media cair. Selain itu, kematian juga bisa diakibatkan karena adanya kondisi kultur secara keseluruhan yakni guncangan shaker dan penyinaran secara terus-menerus selama kultur, serta penggantian media secara periodik setiap minggu.

\section{Laju Regenerasi}

Laju regenerasi tertinggi dihasilkan pada formula A. Besarnya laju regenerasi untuk masing-masing formula adalah sebagai berikut: A (41,67\%); C (33,33\%); E (33,33\%); B (25\%); D (25\%), sedangkan kontrol tidak mengalami regenerasi (0\%). Hasil uji keragaman (ANOVA) menunjukkan bahwa penambahan zat pengatur tumbuh yang berbeda berpengaruh nyata $(P<0,05)$ terhadap laju regenerasi kalus. Antara perlakuan $\mathrm{A}, \mathrm{B}, \mathrm{C}, \mathrm{D}$, dan $\mathrm{E}$ tidak berbeda nyata $(P>0,05)$, tetapi semua perlakuan berbeda nyata dengan kontrol $(P<0,05)$ (Gambar 6 ).

Hasil yang diperoleh pada penelitian ini sesuai dengan penelitian Mussio \& Rusig (2009) yang memperoleh laju regenerasi Laminaria digitata pada kisaran 25\%-50\% dengan penambahan zat pengatur tumbuh 2,4-dichlorophenoxyacetic acid (2,4-D). 


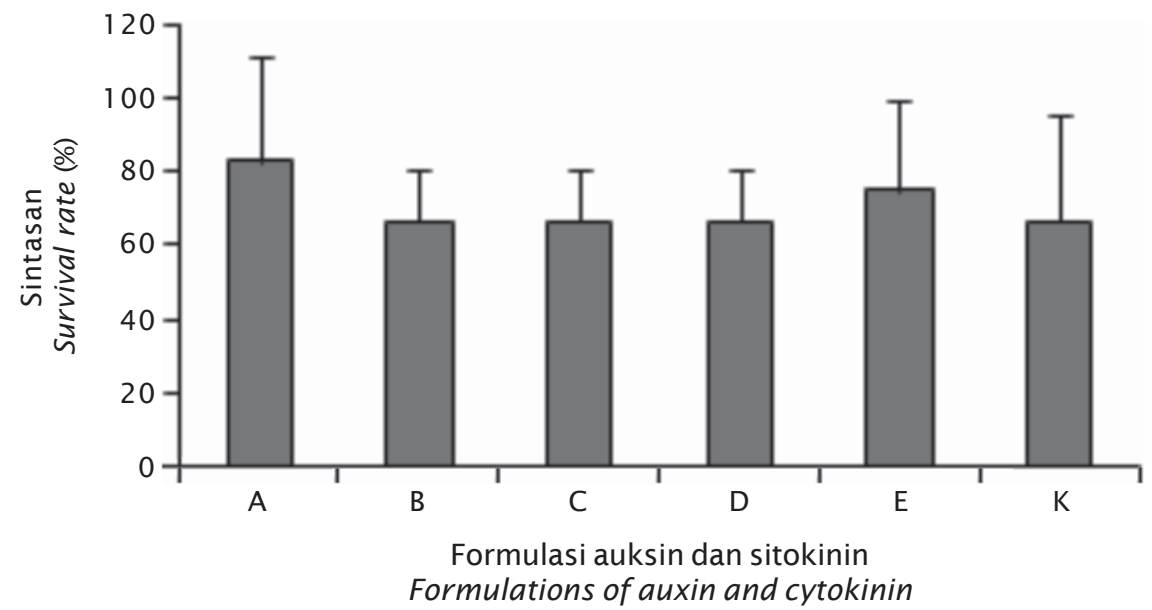

Keterangan (Note):

- IAA + kinetin + zeatin : $A=0,4: 0,1 \mathrm{mg} / \mathrm{L} ; B=0,4: 0,25: 0,75 \mathrm{mg} / \mathrm{L} ; C=0,4: 0,5: 0,5 \mathrm{mg} / \mathrm{L}$; $\mathrm{D}=0,4: 0,75: 0,25 \mathrm{mg} / \mathrm{L} ; \mathrm{E}=0,4: 1: 0 \mathrm{mg} / \mathrm{L} ; \mathrm{K}=$ Kontrol $(\mathrm{IAA}+$ kinetin + zeatin $: A=0.4: 0.1$ $\mathrm{mg} / \mathrm{L} ; B=0.4: 0.25: 0.75 \mathrm{mg} / \mathrm{L} ; C=0.4: 0.5: 0.5 \mathrm{mg} / \mathrm{L} ; D=0.4: 0.75: 0.25 \mathrm{mg} / \mathrm{L} ; E=0.4: 1.0$ $\mathrm{mg} / \mathrm{L} ; \mathrm{K}=$ Control)

- Data disajikan dalam rata-rata \pm deviasi standar, $(n=3$, setiap ulangan terdiri atas 4 kalus) (Data are means \pm standard deviations ( $n=3$, each replicate with four calluses))

Gambar 5. Sintasan kalus pada berbagai formulasi auksin dan sitokinin

Figure 5. Survival rate of callus in several auxin-cytokinin formulation

Kombinasi zat pengatur tumbuh golongan auksin dan sitokinin dapat membantu proses regenerasi kalus rumput laut $K$. alvarezii. Kombinasi IAA : zeatin memiliki efek lebih baik dibandingkan IAA : kinetin. Kombinasi auksin dan zeatin memiliki efek regenerasi yang lebih tinggi dibandingkan kombinasi auksin dan kinetin. Perbedaan ini sangat dipengaruhi karakter dari zat pengatur tumbuh, di mana zeatin diketahui memiliki aktivitas yang lebih tinggi dibandingkan kinetin (Bradley \& Cheney, 1990; Sakakibara, 2006).

\section{Panjang Tunas}

Panjang tunas tertinggi diperoleh pada formula $A(44,59 \pm 4,68 \mu \mathrm{m})$ yang berbeda nyata dengan formula $E(30,50 \pm 4,44 \mu \mathrm{m})$; $C$ $(17,33 \pm 5,01 \mu \mathrm{m})$; D $(15,67 \pm 6,03 \mu \mathrm{m}) ; \mathrm{B}$ $(14,33 \pm 6,66 \mu \mathrm{m})$, dan kontrol (0). Dari hasil analisis ragam (ANOVA) menunjukkan bahwa penggunaan formulasi zat pengatur tumbuh yang berbeda berpengaruh nyata $(P<0,05)$ terhadap panjang tunas. Semua perlakuan formula zat pengatur tumbuh memiliki panjang tunas yang berbeda nyata dengan kontrol $(P<0,05)$. Formula $E$ berbeda nyata dengan formula $B, C, D$, dan kontrol $(P<0,05)$. Sedangkan formula $B, C$, dan D masing-masing tidak berbeda nyata $(P>0,05)($ Gambar 7$)$.

Penelitian terdahulu memberikan informasi yang beragam mengenai ukuran tunas yang dihasilkan. Huang et al. (1999), memperoleh panjang tunas untuk rumput laut Grateloupia turuturu pada kisaran 3-5 mm setelah 8 minggu pemeliharaan; Yokoya (2000) memperoleh panjang tunas Gracilariopsis tenuifrons pada kisaran 0,2-4,5 mm; sedangkan Hurtado et al. (2008) memperoleh panjang tunas beberapa varietas Kappaphycus pada kisaran 1-3 mm. Perbedaan hasil ini dikarenakan adanya perbedaan jenis rumput laut, jenis zat pengatur tumbuh, dan media kultur yang digunakan. Dalam kultur in vitro zat pengatur tumbuh berperan mengontrol pertumbuhan, proses pembentukkan tunas rumput laut. Panjang tunas yang diperoleh sangat dipengaruhi oleh jenis zat pengatur tumbuh dan media yang digunakan (Yokoya \& Handro, 1996; Yokoya \& Handro, 2002).

\section{Perkembangan Morfologi}

Pada penelitian ini, tunas rumput laut mulai terbentuk pada umur pemeliharaan 15 hari. Semua formula zat pengatur tumbuh kombinasi 


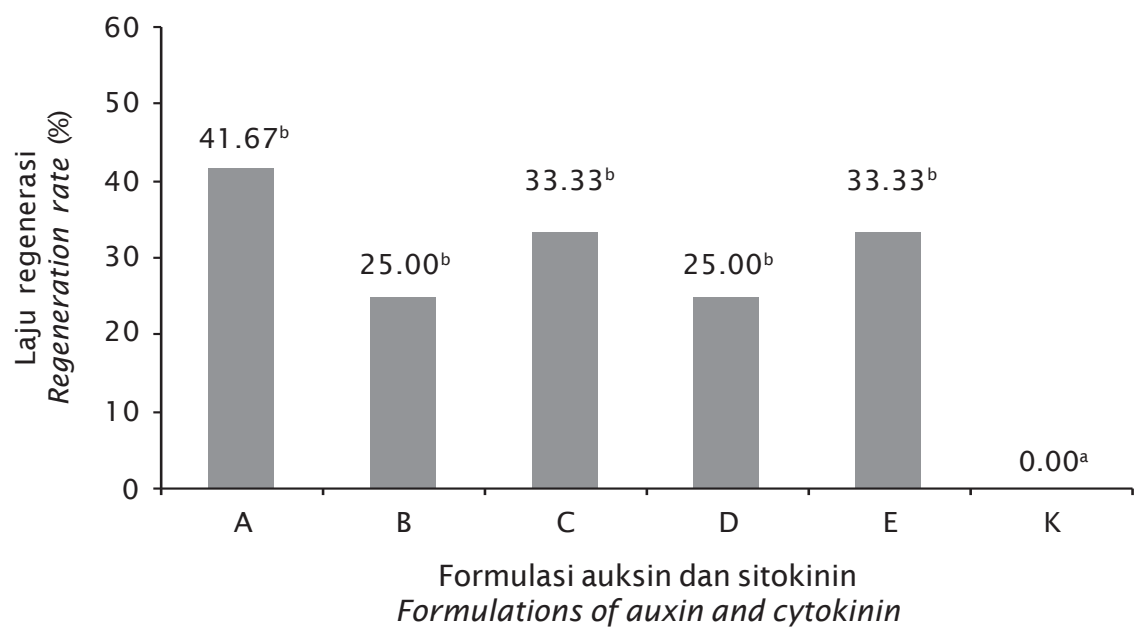

Keterangan (Note):

- IAA + kinetin + zeatin : A = 0,4:0,1 mg/L; B = 0,4:0,25:0,75 mg/L; C = 0,4:0,5:0,5 mg/L; $\mathrm{D}=0,4: 0,75: 0,25 \mathrm{mg} / \mathrm{L} ; \mathrm{E}=0,4: 1: 0 \mathrm{mg} / \mathrm{L} ; \mathrm{K}=$ Kontrol $(I A A+$ kinetin + zeatin $: A=0.4: 0.1$ $\mathrm{mg} / \mathrm{L} ; B=0.4: 0.25: 0.75 \mathrm{mg} / \mathrm{L} ; C=0.4: 0.5: 0.5 \mathrm{mg} / \mathrm{L} ; D=0.4: 0.75: 0.25 \mathrm{mg} / \mathrm{L} ; E=0.4: 1.0$ $\mathrm{mg} / \mathrm{L} ; K=$ Control)

- Nilai yang diikuti oleh huruf yang sama setelah nilai rata-rata menunjukkan berbeda tidak nyata $(P>0,05)$ pada uji Duncan. Data disajikan dalam rata-rata \pm standar deviasi, ( $\mathrm{n}=3$, setiap ulangan terdiri atas 4 kalus) (Values with the same superscripts after means value are not significantly different $(P>0.05)$ in Duncan test. Data are means \pm standard deviations ( $n=3$, each replicate with four calluses))

Gambar 6. Laju regenerasi kalus pada berbagai formulasi auksin dan sitokinin

Figure 6. Regeneration rate of callus in several auxin-cytokinin formulation

auksin dan sitokinin yang digunakan dalam penelitian ini memberikan efek regenerasi dan berpengaruh terhadap pertumbuhan rumput laut. Hal ini berbeda dengan kontrol yang tidak mengalami regenerasi. Konsentrasi sitokinin yang lebih tinggi daripada auksin dapat menstimulasi pembelahan sel, dengan meningkatkan sintesis protein dan aktivitas metabolisme pada proses diferensiasi sel. Kombinasi auksin dan sitokinin mampu menstimulasi regenerasi kalus serta memiliki peran regulasi dalam pertumbuhan dan morfogenesis (Yokoya \& Handro, 1996; Yokoya et al., 2004; Reddy et al., 2003).

Berdasarkan suatu hipotesis yang disebut hipotesis pertumbuhan asam (acid growth hypothesis), golongan auksin berperan dalam pembesaran sel. Zat pengatur tumbuh golongan auksin dapat memicu pompa proton untuk meningkatkan jumlah $\mathrm{H}+$ ke dalam sel sehingga sitoplasma sel menjadi lebih asam kemudian menyebabkan melonggarnya ikatan polisakarida pada dinding sel. Dengan demikian air dengan mudah berosmosis ke dalam sel dan menyebabkan sel mengalami pembesaran. Pembentukkan tunas ditandai dengan memadatnya filamen dan kemudian beregenerasi membentuk tunas. Hal ini bisa teramati di bawah mikroskop, filamen kalus yang memadat akan membentuk tunas. Pada kontrol tidak terjadi pemadatan filamen kalus sehingga tidak terbentuk tunas (Gambar 8) (Dewi, 2008; Huang et al., 1998).

Kombinasi auksin dan sitokinin memiliki efek stimulasi pada pembentukkan kalus, pertumbuhan dan regenerasi. Auksin dan sitokinin eksogen yang ditambahkan akan berinteraksi dengan hormon endogen tanaman dan jaringan akan menanggapi aplikasi hormon eksogen tersebut. Auksin memiliki pengaruh yang kuat pada proses-proses seperti ekspansi pertumbuhan sel, pengasaman dinding sel, dan mempercepat diferensiasi vaskular. Banyak aspek pertumbuhan sel, diferensiasi sel, dan organogenesis dalam kultur jaringan dan organ tubuh ditemukan dikontrol oleh interaksi antara sitokinin dan auksin. Konsentrasi setiap zat pengatur 


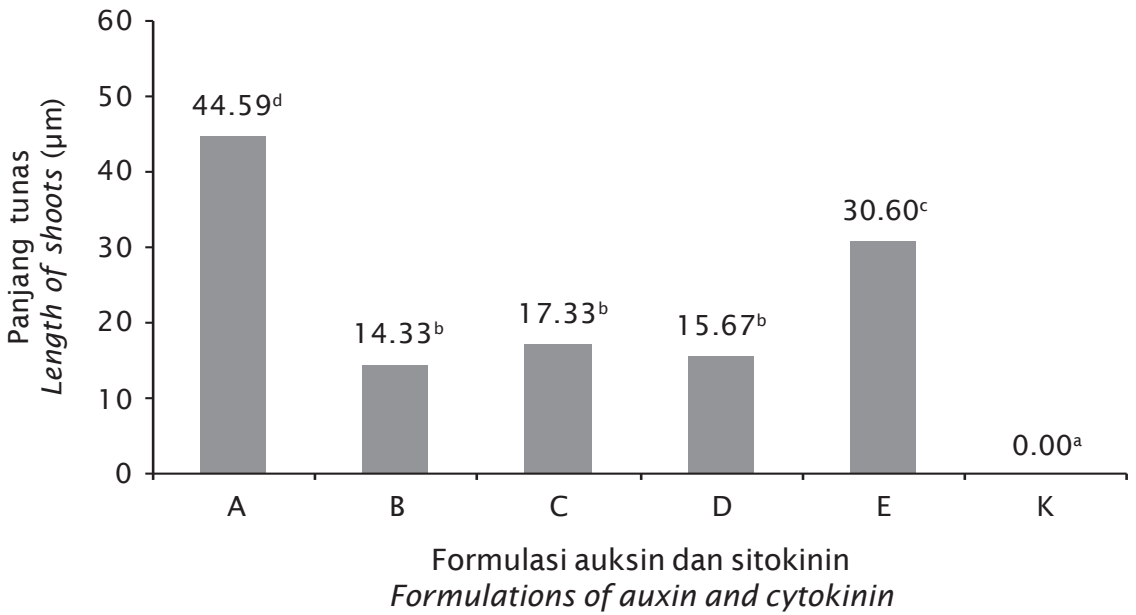

Keterangan (Note):

- IAA + kinetin + zeatin : $A=0,4: 0,1 \mathrm{mg} / \mathrm{L} ; B=0,4: 0,25: 0,75 \mathrm{mg} / \mathrm{L} ; C=0,4: 0,5: 0,5 \mathrm{mg} / \mathrm{L}$; $\mathrm{D}=0,4: 0,75: 0,25 \mathrm{mg} / \mathrm{L} ; \mathrm{E}=0,4: 1: 0 \mathrm{mg} / \mathrm{L} ; \mathrm{K}=$ Kontrol $(I A A+$ kinetin + zeatin : $A=0.4: 0.1$ $\mathrm{mg} / \mathrm{L} ; B=0.4: 0.25: 0.75 \mathrm{mg} / \mathrm{L} ; C=0.4: 0.5: 0.5 \mathrm{mg} / \mathrm{L} ; D=0.4: 0.75: 0.25 \mathrm{mg} / \mathrm{L} ; E=0.4: 1.0$ $\mathrm{mg} / \mathrm{L} ; \mathrm{K}=$ Control)

- Nilai yang diikuti oleh huruf yang sama setelah nilai rata-rata menunjukkan berbeda tidak nyata $(P>0,05)$ pada uji Duncan. Data disajikan dalam rata-rata \pm standar deviasi, ( $n=3$, setiap ulangan terdiri atas 4 kalus) (Values with the same superscripts after means value are not significantly different $(P>0.05)$ in Duncan test. Data are means \pm standard deviations ( $n=3$, each replicate with four calluses))

Gambar 7. Panjang tunas rumput laut K. alvarezii pada berbagai formulasi auksin dan sitokinin

Figure 7. Shoots length of $\mathrm{K}$. alvarezii in several auxin-cytokinin formulation
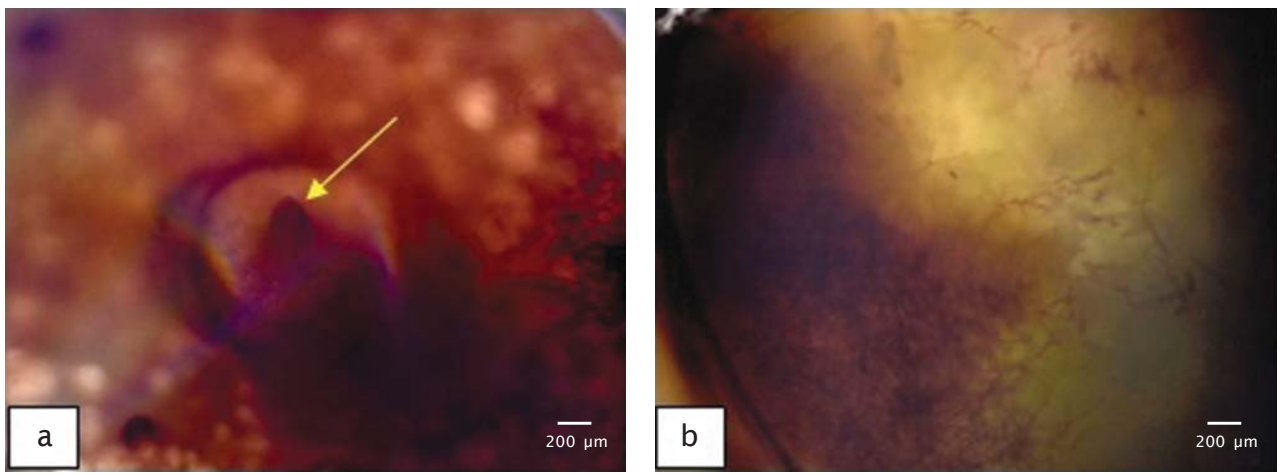

Gambar 8. Morfologi tunas rumput laut K. alvarezii: a. kalus yang membentuk tunas (tanda panah); b. kalus yang tidak membentuk tunas (skala bar $=20 \mu \mathrm{m}$ )

Figure 8. Shoot morphology of K. alvarezii: a. callus with seaweed shoot (arrow); b. callus without shoot (scale bar $=20 \mu \mathrm{m}$ )

tumbuh sangat bervariasi sesuai dengan jenis tanaman yang dikultur, kondisi kultur, dan bentuk zat pengatur tumbuh yang digunakan (Gaspar et al., 1996; Reddy et al., 2008b).

\section{KESIMPULAN}

1. Formula optimum untuk morfogenesis rumput laut $K$. alvarezii adalah formula $A$ dengan komposisi IAA : zeatin =0,4:1 mg/L. 
2. Penggunaan formula zat pengatur tumbuh yang berbeda berpengaruh nyata $(P<0,05)$ terhadap laju pertumbuhan harian, laju regenerasi, dan panjang tunas yang dihasilkan, tetapi tidak berpengaruh nyata $(P>0,05)$ terhadap sintasan kalus.

\section{UCAPAN TERIMA KASIH}

Terima kasih disampaikan kepada Dra. Emma Suryati, M.Si. dan Siti Fadilah, S.Si. yang banyak membantu dalam kegiatan penelitian.

\section{DAFTAR ACUAN}

Bradley, P.M. \& Cheney, D.P. 1990. Some effects of plant growth regulators on tissue cultures of the marine red alga Agardhiella subulata (Gigartinales, Rhodophyta). Hydrobiologia, 204/205: 353-360.

Dewi, I.R. 2008. Peranan dan Fungsi Fitohormon Bagi Pertumbuhan Tanaman. Makalah. Fakultas Pertanian Universitas Padjadjaran, Bandung, $36 \mathrm{hlm}$.

Gaspar, T., Kevers, C., Penel, C., Greppin, H., Reid, D.M., \& Thorpe, T.A. 1996. Plant Hormones and Plant Growth Regulators In Plant Tissue Culture. Vitro Cell Dev. Biol. Plant, 32: 272-289.

Gonzalez, M.C.H., Buschmann, A.H., Cifuentes, M., Correa, J. A., \& Westermeier, R. 2007. Vegetative propagation of the carrageenophytic red alga Gigartina skottsbergii Setchell et Gardner: Indoor and field experiments. Aquaculture, 262: 120-128.

Hayashi, L., Yokoya, N.S., Kikuchi, D.M., \& Oliveira, E.C. 2008. Callus Induction and Micropropagation Improved By Colchicine and Phytoregulators in Kappaphycus alvarezii (Rhodophyta, Solieriaceae). J. Appl. Phycol., 20: 653-659.

Huang, W., Fujita, Y., Ninomiya, M., \& Ohno, M. 1999. Seed production and cultivation of Grateloupia turuturu (Cryptonemiales, Rhodophyta) by callus culture. Bull. Mar. Sci. Fish., 19: 1-7.

Huang, Y., Maliakal, S., Cheney, D.P., \& Rorrer, G.L. 1998. Comparison of development and photosynthetic growth for filament clump and regenerated microplantlet culture of Agardhiella subulata (Rhodophyta, Gigartinales). J. Phycol., 34: 893-901.

Hurtado, A.Q., Yunque, D.A., Tibubos, K., \& Critchley, A.T. 2009. Use of Acadian marine plant extract powder from Ascophyllum nodosum in tissue culture of Kappaphycus varieties. J. Appl. Phycol., 21 (6): 633-639.

Kumar, G.R., Reddy, C.R.K., Ganesan, M., Thiruppathi, S., Dipakkore, S., Eswaran, K., Rao P.V.S., \& Jha, B. 2004. Tissue culture and regeneration of thallus from callus of Gelidiella acerosa (Gelidiales, Rhodophyta). Phycologia, 43(5): 596-602.

Kumar, G.R., Reddy, C.R.K., \&Jha, B. 2007. Callus induction and thallus regeneration from callus of phycocoloid yielding seaweeds from Indian coast. J. Appl. Phycol., 19: 1525.

Munõz, J., Lõpez, A.C.C., Patiño, R., \& Robledo, D. 2006. Use of plant plant growth regulators in micropropagation of Kappaphycus alvarezii (Doty) in airlift bioreactors. J. Appl. Phycol., 18: 209-218.

Mussio, I. \& Rusig, A.M. 2009. Morphogenetic responses from protoplasts and tissue culture of Laminaria digitata (Linnaeus) J.V. Lamouroux (Laminariales, Phaeophyta): callus and thalloid-like structures regeneration. J. Appl. Phycol., 21: 255-264.

Parenrengi, A., Suryati, E., \& Rachmansyah. 2007. Penyediaan Benih Dalam Menunjang Kebun Bibit dan Budidaya Rumput Laut, Kappaphycus alvarezii. Makalah disampaikan pada Simposium Nasional Riset Kelautan dan Perikanan, Jakarta, 7 Agustus 2007. $12 \mathrm{hlm}$.

Prakoeswa, S.A., Ribkahwati, \& Suryaningsih, D.R. 2009. Teknik Kultur Jaringan Tanaman: Implementasi Beserta Aplikasi dan Hasil Penelitian. Dian Prima Lestari. Sidoarjo, 272 hlm.

Reddy, C.R.K., Kumar, G.R., Siddhanta, A.K., \& Tewari, A. 2003. In vitro somatic embryogenesis and regeneration of somatic embryos from pigmented callus of Kappaphycus alvarezii (Doty) Doty (Rhodophyta, Gigartinales). J. Phycol., 39: 610-616.

Reddy, C.R.K., Jha, B., Fujita, Y., \& Ohno, M. 2008a. Seaweed micropropagation techniques and their potentials : an overview. J. Appl. Phycol., 20: 609-617.

Reddy, C.R.K., Gupta, M.K., Mantri, V.A., \&Jha, B. 2008b. Seaweed protoplasts: status, biotechnological prospective and needs. J. Appl. Phycol., 20: 619-632.

Rorrer, G.L. \& Cheney, D.P. 2004. Bioprocess engineering of cell and tissue cultures for marine seaweeds. Aquacultural Engineering, 32: 11-41. 
Sakakibara, H. 2006. Cytokinins: Activity, Biosynthesis, and Translocation. Annual Review Plant Biology, 27: 431-49.

Wang, A., Shuai, L., \& Duan, D. 2006. Filament induction in Halymenia sinensis (Halymeniaceae, Rhodophyta). Botanica Marina, 49: 352-354.

Yokoya, N.S. \& Handro, W. 1996. Effect of auxins and cytokinins on tissue culture of Grateloupia dichotoma (Gigartinales, Rhodophyta). Hydrobiologia, 326/327: 393-400.

Yokoya, N.S. 2000. Apical callus formation and plant regeneration controlled by plant growth regulators on axenic culture of the red alga Gracilariopsis tenuifrons (Gracilariales, Rhodophyta). Phycological Research, 48: 133-142.

Yokoya, N.S. \& Handro, W. 2002. Effect of plant growth regulators and culture medium on morphogenesis of Solieria filiformis (Rhodophyta) culture in vitro. J. App. Phycol., 14: 97-102.

Yokoya, N.S., West, J.A., \& Luchi, A.E. 2004. Effects of plant growth regulators on callus formation, growth and regeneration in axenic tissue cultures of Gracilaria tenuistipitata and Gracilaria perplexa (Gracilariales, Rhodophyta). Phycological Research, 52: 244-25 